\title{
INFORMATIVITY OF RADIONUCLIDE RENAL SCINTIGRAPHY AND BIOCHEMICAL MARKERS IN DETECTION OF RENAL DYSFUNCTION IN PATIENTS UNDERGOING MYOCARDIAL REVASCULARIZATION
}

\author{
Vesnina Zh.V., Kozlov B.N., Lishmanov Yu.B.
}

Cardiology Research Institute, Tomsk National Research Medical Centre, Russian Academy of Sciences.

Tomsk, Russia. biochemical markers in the detection of renal dysfunction in patients with coronary artery disease (CAD) in the early postoperative period after coronary artery bypass grafting (CABG).

Material and methods. A randomized controlled trial comprised a total of $108 \mathrm{CAD}$ patients (all men aged $54.94 \pm 0.72$ years) who underwent direct myocardial revascularization by CABG. All patients received dynamic renal scintigraphy with 99mTc-DTPA and blood tests measuring serum concentrations of creatinine, lipocalin (NGAL), and Cystatin $\mathrm{C}$ before and after CABG.

Results. After CABG, the mean values of total glomerular filtration rate (GFR) and GFR for each kidney significantly decreased whereas the serum concentrations of neutrophil gelatinase-associated lipocalin (NGAL) and Cystatin C in blood serum significantly increased.

In the postoperative period, the creatinine clearance also significantly decreased. Statistical analysis revealed direct correlations of cardiopulmonary bypass duration with the changes in GFR $(\mathrm{R}=0.42 ; \mathrm{P}=0.017)$ and $\mathrm{s}-\mathrm{NGAL}(\mathrm{R}=0.39, \mathrm{P}=0.02)$ in cardiac surgery patients.

Conclusion. Radionuclide method is not inferior to testing biochemical markers in the evaluation of early postoperative renal dysfunction in regard to diagnostic value and informativeness.

Keywords: dynamic renal scintigraphy, NGAL, Cystatin C, renal dysfunction, coronary artery bypass grafting.

Corresponding author: Vesnina Zh.V., e-mail: zhvesnina@mail.ru

For citation: Vesnina Zh.V., Kozlov B.N., Lishmanov Yu.B. Informativity of radionuclide renal scintigraphy and biochemical markers in detection of renal dysfunction in patients undergoing myocardial revascularization. REJR 2021; 11(1):144-150. DOI: 10.21569/22227415-2021-11-1-144-150.

Received: $\quad 30.09 .20 \quad$ Accepted: $\quad 04.02 .21$

\section{ИНФОРМАТИВНОСТЬ РААИОНУКАИАНОЙ СЦИНТИГРАФИИ ПОЧЕК И БИОХИМИЧЕСКИХ МАРКЕРОВ ПРИ ВЫЯВАЕНИИ ПОЧЕЧНОЙ НЕАОСТАТОЧНОСТИ У ПАЦИЕНТОВ С РЕВАСКУАЯРИЗАЦИЕЙ МИОКАРАА}

\author{
Веснина Ж.В., Коз^ов Б.Н., Аишманов Ю.Б.
}

НИИ кардиологии, Томский национальный исследовательский медищинский центр Российской Академии наук. г. Томск, Россия. 
биохимических маркеров в выявлении нарушений функции почек у пациентов с ишемической болезнью сердца (ИБС) в раннем послеоперационном периоде после аортокоронарного шунтирования (АКШ).

Материал и методы. В рандомизированном контролируемом исследовании приняли участие 108 пациентов с ИБС (все мужчины в возрасте 54,94 \pm 0,72 года), которым была выполнена прямая реваскуляризация миокарда методом АКШ. Всем пациентам была проведена динамическая сцинтиграфия почек с 99mTc-DTPA и ана-

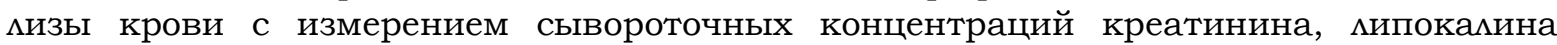
(NGAL) и цистатина С до и после АКШ.

Результаты. После АКШ средние значения общей скорости клубочковой фильтрации (СКФ) и СКФ для каждой почки значительно снизились, тогда как сывороточные концентрации мипокалина, связанного с желатиназой нейтрофилов (NGAL) и цистатина С в сыворотке крови, значительно увеличились. В послеоперационном периоде также значительно снизился клиренс креатинина. Статистический анализ выявиц прямую корреляцию продолжительности искусственного кровообращения с изменениями СКФ (R = 0,42; $\mathrm{P}=0,017)$ и $\mathrm{s}-\mathrm{NGAL}(\mathrm{R}=0,39, \mathrm{P}=0,02)$ у кардиохирургических пациентов.

Заключение. Радионуклидный метод по диагностической значимости и информативности не уступает биохимическим маркерам в оценке раннего послеоперационного нарушения функции почек.

К^ючевые слова: динамическая сцинтиграфия почек, NGAL, цистатин C, почечная дисфункция, аортокоронарное шунтирование.

Контактный автор: Веснина Ж.В., e-mail: zhvesnina@mail.ru

Для иитирования: Веснина Ж.В., Козлов Б.Н., Аишманов Ю.Б. Информативность радионуклидной сиинтиграфии почек и биохимических маркеров при въявлении почечной недостаточности у пайентов с реваскуляризайией миокарда. REJR 2021; 11(1):144-150. DOI: 10.21569/2222-7415-2021-11-1-144-150.
Статья получена:
30.09.20
Статья принята:
04.02.21

\section{I}

\section{ntroduction.}

Coronary artery bypass grafting surgery (CABG) is among the most effective methods of treatment for coronary heart disease. At the same time, acute changes in renal function after $\mathrm{CABG}$ represent a challenging clinical problem [1-3]. Transient renal dysfunction and/or acute kidney injury (AKI) may be observed after open heart surgery with cardiopulmonary bypass in $5-28 \%$ of patients (according to other data - in up to $40 \%$ of patients), regardless of age and the condition of the cardiovascular system $[4,5]$. In this case, the development of renal dysfunction even if transient can seriously impact the duration of hospital treatment and prognosis of underlying disease $[3,6]$.

Currently, in cardiac surgery practice, AKI diagnosis is based on the assessments of urinary output, serum creatinine ( $\mathrm{SCr}$ ), and/or $\mathrm{SCr}$ clearance $[1,3,7]$. This classification has proven to be valuable in evaluating the risk of short- and longterm complications in patients with ischemic renal damage. Creatinine clearance can be calculated based on SCr values, which, according to many researchers, reflect GFR [3, 8]. In turn, GFR reduction is one of the main manifestations of renal dysfunction. Two methods of calculation are primarily used: Cockcroft-Gault formula and MDRD formula (The Modification of Diet in Renal Disease Study) $[9,10]$.

However, traditional markers such as creatinine and urea concentrations are sensitive not enough for early AKI diagnosis, since the changes in $\mathrm{SCr}$ do not reflect the corresponding GFR decrease in some cases [7, 11]. The kidneys have a significant functional reserve, so the creatinine concentration does not change until the renal parenchyma loses about $60 \%[11,12]$. In addition, $\mathrm{SCr}$ can vary over a wide range, depending on many extrarenal factors [12]. Therefore, creatinine is not an ideal marker for measuring GFR.

Cystatin C, a cationic low-molecular-weight cysteine protease, produced by all nucleated cells with a constant rate and not metabolized in serum, has been proposed as a glomerular test agent (GFR surrogate). The production of Cystatin 
C, unlike creatinine, is considered to be lowdependent on various factors: age, sex, muscle mass, and hydrovolemia [13]. It is generally accepted that over $99 \%$ cystatin C elimination is due to glomerular filtration [13, 14]. Thus, the assessment of this marker allows to detect AKI development earlier and with greater specificity than serum creatinine measurements [15].

Neutrophil gelatinase-associated lipocalin (NGAL) may be even earlier predictor of AKI. NGAL expression is increased in the cells of tubular epithelium multifold in the presence of ischemic and toxic kidney injury. Blood plasma NGAL concentrations (s-NGAL) and NGAL excretion with urine (u-NGAL) increase 24-48 hours before the rise in creatinine level and 10 hours before the increase in serum Cystatin $\mathrm{C}$ concentration $[15,16]$. Therefore, there is a reason to consider NGAL an early sensitive non-invasive AKI marker [17]. Moreover, the levels of s-NGAL and u-NGAL have similar diagnostic and prognostic significances [18].
However, the assessment of cystatin $\mathrm{C}$ and lipocalin levels has not been widely implemented in everyday clinical practice.

The function of urinary system can be studied using radionuclide research methods enabling to assess glomerular filtration, tubular secretion, urodynamics, the state of parenchyma and blood supply to the kidneys, topography of the entire organ, and its individual parts [17]. In particular, radionuclide renal scintigraphy enables to detect abnormalities in the renal function at early stages of disease and to diagnose the severity and the level of damage, when clinical and/or biochemical manifestations are yet absent [17].

The purpose of this investigation was to evaluate the diagnostic significance of radionuclide renal scintigraphy and biochemical markers in the detection of renal dysfunction in patients with coronary artery disease in the early postoperative period after CABG.

Material and methods

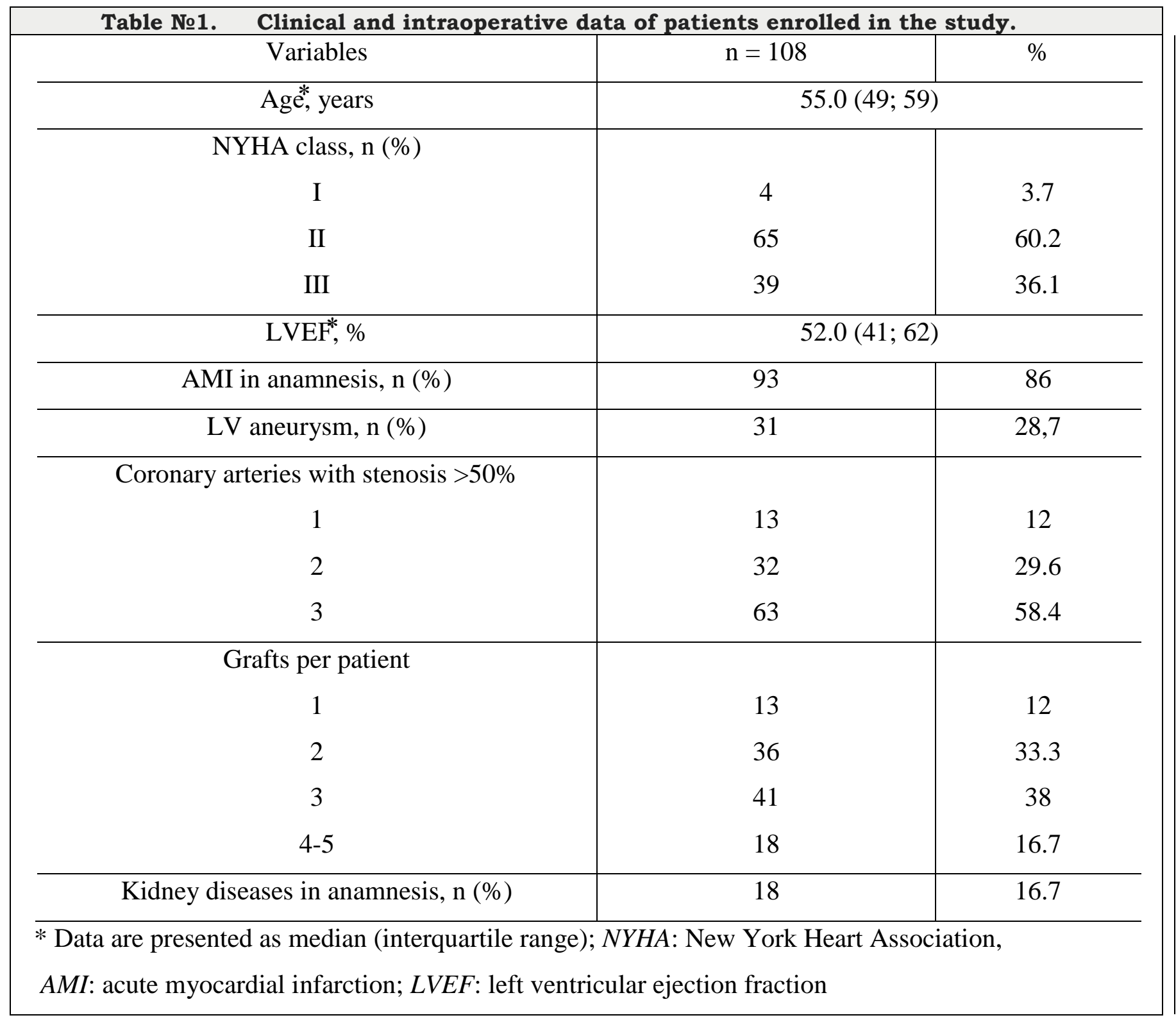




\section{Patient selection.}

A total of 108 patients (all men aged $54.94 \pm$ 7.25 years) who underwent first-time CABG were enrolled in the study. All patients had the following primary diagnosis: CAD with angina pectoris functional class 2 to 4 , complicated by CHF NYHA I-III. Ninety-three (86\%) patients suffered one or more acute myocardial infarctions with the formation of postinfarction cardiosclerosis. The clinical profiles of the matched patients are described in Table 1.

All consecutive patients were examined after informed consent was obtained. All patients underwent dynamic renal scintigraphy with 99mTcdiethylenetriaminepentaacetic acid (99mTc-DTPA) before and 6-7 days after CABG and were subjected to measuring the concentration of $\mathrm{SCr}$ in the time period not exceeding 48 hours from the day of renal scintigraphy. The following parameters were calculated in the course of the study: total glomerular filtration rate (GFR, $\mathrm{mL} / \mathrm{min}$ ) and GFRs for each kidney; blood clearance (min) as half-time of radiopharmaceutical excretion from blood; creatinine clearance in blood serum prior to $\mathrm{CABG}$ and 5 hours after the beginning of the operation.

Forty patients were subjected to measuring the blood serum amounts of lipocalin-2 prior to $\mathrm{CABG}$ and 5 hours after the beginning of surgery and Cystatin $\mathrm{C}$ before and 24 hours after surgery.

Renal Function Evaluation.

Dynamic renal scintigraphy with 99mTcDTPA was performed in a sitting position of a patient whose back faced a detector of the gammacamera so that the heart and the kidneys were within the field of view. The radiopharmaceutical was introduced intravenously at a dose of 30-40 $\mathrm{mBq}(0.8-1.0 \mathrm{mCi})$ and a volume of 1.0 to $1.5 \mathrm{~mL}$. To calculate GFR, syringe activity was recorded before and after the infusion of radiopharmaceutical to a patient.

All the scintigraphic studies were performed with gamma camera Philips Forte (Philips Medical Systems, Netherlands). Processing of the acquired scintigrams was performed using JetStream ${ }^{\circledR}$ Workspace Release 3.0 software package (Philips Medical Systems, Netherlands).

Laboratory Methods.

Serum NGAL was tested by Human Lipocalin-2/NGAL ELISA kit; serum Cystatin C was assessed by Human Cystatin C ELISA (ELISA, BioVendor Laboratory Medicine, Inc.). The principle of the technique was based on quantitative solid phase immunoenzyme sandwich analysis. The Cockcroft-Gault equation was used to calculate creatinine clearance [9].

Statistical analysis.

Statistical analysis was performed with STATISTICA software. To evaluate significance of differences between dependent samples, nonparametric Wilcoxon rank-sum test and Sign-test were used. To detect the presence of correlation relationships between data, Spearman rank correlation coefficient was used. For all statistical evaluations, differences in data with $\mathrm{p}$-values of less than 0.05 were considered statistically significant.

\section{Results.}

Before surgery, initial reduction of varying degree in GFR in one or two kidneys was found in $80(74.1 \%)$ patients. The mean GFR values were $107.72 \pm 9.75 \mathrm{~mL} / \mathrm{min}$ (total GFR): $49.96 \pm 7.37$ $\mathrm{mL} / \mathrm{min}$ for the left kidney and 57.72 \pm 6.01

\begin{tabular}{|c|c|c|c|}
\hline $\begin{array}{c}\text { Table №2. } \\
\text { distribution (plan) and }\end{array}$ & $\begin{array}{l}\text { parative results of the } \\
\text { e total delivered dose }\end{array}$ & $\begin{array}{l}\text { analysis for two cases } \\
\text { ibution for } 6 \text { fractions (s) }\end{array}$ & anned \\
\hline Variables & Before CABG & After CABG & P-level \\
\hline Creatinine, $\mathrm{mM} / \mathrm{L}$ & $89.0(81 ; 97)$ & $92.0(82.2 ; 102)$ & 0.236 \\
\hline $\begin{array}{l}\text { Creatinine clearance, } \\
\mathrm{mL} / \mathrm{min}\end{array}$ & $97.8(78.3 ; 122.8)$ & $75.5(52.9 ; 99.1)$ & $<0.05$ \\
\hline Total GFR, mL/min & $109.95(104.25 ; 113.75)$ & $99.45(92.65 ; 107.55)$ & $<0.01$ \\
\hline Blood clearance, min & $17.5(16.2 ; 20.1)$ & $22.4(20.6 ; 24.4)$ & $<0.01$ \\
\hline GFR left, $\mathrm{mL} / \mathrm{min}$ & $50.3(45.9 ; 56.3)$ & $44.55(39.25 ; 52,90)$ & $<0.01$ \\
\hline GFR right, $\mathrm{mL} / \mathrm{min}$ & $59.1(55.3 ; 62.15)$ & $52.85(48.4 ; 57.25)$ & $<0.01$ \\
\hline Lipocalin, ng/mL & 53.07 (41.46; 82.64) & $143.75(131.27 ; 214.71)$ & $<0.01$ \\
\hline Cystatin $\mathrm{C}, \mathrm{ng} / \mathrm{mL}$ & $721.0(613.4 ; 794.95)$ & $954.35(697.25 ; 1068.00)$ & $<0.05$ \\
\hline
\end{tabular}


$\mathrm{mL} / \mathrm{min}$ for the right kidney (Table 2).

We found pronounced renal dysfunction (the GFR decline in one or both kidneys by more than $30 \%$ of normal values) in $12(11.1 \%)$ patients; 48 $(44.4 \%)$ patients had moderate disturbance of the filtration function. It should be noted, that only 18 $(16.7 \%)$ individuals had chronic kidney disease in the past medical history. Statistical analysis allowed to detect the presence of correlation relationship between GFR determined by the radionuclide method and $\mathrm{SCr}$ clearance $(\mathrm{R}=0.30, \mathrm{p}=$ 0.005).

In our study, the mean value of lipocalin-2 in all patients before surgical treatment was 67.02 $\pm 41.99 \mathrm{ng} / \mathrm{mL}$ which exceeded the corresponding mean value in individuals without cardiovascular diseases (Table 2) [19]. We discovered the inverse relationship between s-NGAL levels and ejection fraction of $\mathrm{LV}(\mathrm{LVEF})$ in study patents $(\mathrm{R}=-0.37$, $\mathrm{p}=0.02)$. Statistical analysis also allowed to detect the presence of the inverse relationship between GFR and lipocalin level in study patents before revascularization $(\mathrm{R}=-0.33, \mathrm{p}=0.03)$.

Table 2 shows the statistically significant changes in the values of renal functional activity after CABG with cardiopulmonary bypass. Indeed, there were significant reduction in the mean values of total GFR and GFR for each kidney as well as statistically significant increase in the blood clearance. Pronounced renal dysfunction (a decrease in total GFR by $15 \%$ and more compared with the initial level) due to nonpulsatile blood flow occurred in $35 \%$ of patients; insignificant decrease in the filtration activity was found in 18 patients $(16.7 \%)$.

Significant increase in the concentration of s-NGAL occurred 5 hours after surgery relative to the preoperative value (from $67.02 \pm 41.99$ to $171.65 \pm 89.91 \mathrm{ng} / \mathrm{mL}, \mathrm{p}<0.001)$. Statistical analysis revealed the significant correlations between the duration of cardiopulmonary bypass and the changes in GFR $(\mathrm{R}=0.42 ; \mathrm{p}=0.017)$, as well as between the duration of cardiopulmonary bypass and the changes in s-NGAL levels in cardiac surgery patients $(R=0.39, p=0.02)$. The clearance of creatinine also significantly decreased in the postoperative period.

Table 2 shows a significant increase in blood serum concentration of Cystatin $\mathrm{C}$, which occurred 24 hours after surgery, relative to preoperative value (from $722.05 \pm 188.31$ to $916.66 \pm$ $283.92 \mathrm{ng} / \mathrm{mL}, \mathrm{p}<0.05)$. However, in comparison with lipocalin, the severity of postoperative increase in cystatin $\mathrm{C}$ was less pronounced. Besides, we could not detect the presence of direct correlation of the cystatin $\mathrm{C}$ levels with cardiopulmonary bypass duration $(\mathrm{R}=0.01, \mathrm{p}=0.95)$ and the cross-clamp time $(\mathrm{R}=0.08, \mathrm{p}=0.73)$.

Discussion.

Abnormal glomerular filtration and the in- creased lipocalin-2 level in preoperative period indicate the development of cardiorenal syndrome caused by chronic heart failure as result of reducing renal perfusion and increasing renal vascular resistance $[20,21]$.

The study showed that the s-NGAL and Cystatin $\mathrm{C}$ levels were associated with cardiovascular diseases including chronic heart failure [19, 22]. Choi K. M. with coworkers demonstrated that mean s-NGAL levels were $82.6 \pm 38.7 \mathrm{ng} / \mathrm{mL}$ in patients with angiographically confirmed coronary artery stenosis versus $43.8 \pm 27.8 \mathrm{ng} / \mathrm{mL}$ in control group [19]. Authors believe that changes in sNGAL level can be useful for evaluation of CAD risk because they are independently associated not only with coronary atherosclerosis, but also with insulin resistance and systolic blood pressure [19]. Ix J.H. with coworkers compared the levels of creatinine and cystatin $\mathrm{C}$ as predictors of an unfavourable prognosis during the Heart and Soul Study [22]. The study showed that the highest quintile of cystatin C ( $\geq 1.3 \mathrm{mg} / \mathrm{L})$ was associated with a significant increase in the risk of allcause mortality, cardiovascular events, and incident heart failure. However, according to our data, the mean level of cystatin $\mathrm{C}$ in the examined patients was $722.05 \pm 188.31 \mathrm{ng} / \mathrm{mL}$ (Table 2), which corresponds to the level of this marker in practically healthy individuals (for men is $0.74 \pm$ $0.10 \mathrm{mg} / \mathrm{L}(740 \pm 100 \mathrm{ng} / \mathrm{mL}))$ [23]. Moreover, our study demonstrated that there was no correlation between the levels of cystatin $\mathrm{C}$ with $\operatorname{LVEF}(\mathrm{p}=$ 0.80 ), as well as with GFR calculated using radionuclide method $(\mathrm{p}=0.21)$.

Several works demonstrated that lipocalin levels significantly correlate with serum creatinine, creatinine clearance, and GFR calculated using MDRD formulas [24-26]. However, in our study, we did not find such a relationship. It may be due to the fact that the plasma NGAL levels are associated not only with the morphologic and functional states of renal tubules, but also with other functions of this protein. In particular, NGAL is involved in recovery of damaged epithelium as a protein of acute phase of inflammation as well as in remodeling of atherosclerotic plagues and myocytes in the presence of myocardial damage [27].

In the context of cardiopulmonary bypass, nonpulsatile blood flow triggers cascade of proinflammatory reactions increasing the levels of circulating catecholamines and mediators of inflammation and acute-phase response including lipocalin $[27,28]$. There is evidence that the early rise in the level of NGAL in blood plasma 2 to $6 \mathrm{~h}$ after cardiac surgery is caused by the lipocalin release into the circulation due to the inflammatory neutrophil activation triggered by surgery [29]. The other adverse side effect of extracorporeal circulation consists in the renal macro- and micro- 
emboli leading to renal vasoconstriction and ischemic injury of renal parenchyma which, in turn, leads to functional disorders of the renal parenchyma (reduction in GFR) and expression of lipocalin as a marker of AKI [17, 28, 30].

The observed increase in the s-NGAL level in cardiac patients during the first hours after surgery agrees with data of other researchers. Mishra J. with coworkers observed an elevation of the lipocalin level in blood plasma $2 \mathrm{~h}$ after the beginning of surgery with cardiopulmonary bypass in children [29]. Authors also found correlation between duration of surgery and changes in the NGAL level [29].

It was proved that a significant increase in the level of Cystatin $\mathrm{C}$ can be informative already in the early stages of renal function impair [31]. Cystatin $\mathrm{C}$ concentration in blood increases 1-2 days before the rise in the level of creatinine and is regarded as a sign of stage I-II AKI in patients in the postoperative period [32]. Despite this, there are the number of questions regarding possible use of cystatin $\mathrm{C}$ as an indicator of AKI. The concentration of cystatin $\mathrm{C}$ in the serum can vary much more than that of $\mathrm{SCr}$ [33]. The factors affecting its concentration include age, sex, height, weight, smoking, serum level of C-reactive protein,

\section{References:}

1. Antunes PE, Prieto D, de Oliveira JF, Antunes MJ. Renal dysfunction after myocardial revascularization. Eur $J$ of Cardiothoracic Surg 2004; 25: 597-604. DOI: 10.1016/j.ejcts.2004.01.010.

2. O'Neal JB, Shaw AD, Billings FT 4th. Acute kidney injury following cardiac surgery: current understanding and future directions. Crit Care. 2016; 20(1): 187. DOI: 10.1186/s13054016-1352-z.

3. Ortega-Loubon C, Fernández-Molina M, Pañeda-Delgado L, Jorge-Monjas P, Carrascal Y. Predictors of Postoperative Acute Kidney Injury after Coronary Artery Bypass Graft Surgery. Braz J Cardiovasc Surg. 2018; 33(4): 323-329. DOI: 10.21470/16789741-2017-0251.

4. Brown JR, Kramer RS, Coca SG, Parikh CR. Duration of acute kidney injury impacts long-term survival after cardiac surgery. Ann Thorac Surg. 2010; 90(4): 1142-1148. DOI: 10.1016/j.athoracsur.2010.04.039.

5. Thakar CV, Arrigain S, Worley S, Yared JP, Paganini EP. A clinical score to predict acute renal failure after cardiac surgery. Clin J Am Soc Nephrol. 2005; 16(1): 162-168. DOI: 10.1681/ASN.2004040331.

6. Ritz E. Minor renal dysfunction: an emerging independent cardiovascular risk factor. Heart 2003; 89: 963-964. DOI:10.1136/heart.89.9.963.

7. Bellomo R, Kellum J, Ronco C. Acute renal failure: Time for consensus. Intensive Care Med 2001; 27: 1685-1688. DOI: 10.1007/s00134-001-1120-6.

8. Thomsen HS, Morcos SK. Contrast media and kidney: European Society of Urogenital Radiology (ESUR) Guidelines. $\mathrm{Br} J$ Radiol 2003; 76: 513-518. DOI: http://dx.doi.org/ 10.1259/ bjr/26964464. steroid therapy, and the presence of rheumatoid arthritis [34, 35]. Svensson A.S. and coworkers demonstrated that processes not related to renal function, in particular, acute inflammation, have a significant effect on postoperative changes in the level of Cystatin $\mathrm{C}$, and this can be mistakenly interpreted as the development of AKI [36]. Therefore, at present, the benefits of determining Cystatin $\mathrm{C}$ for the diagnosis of renal dysfunction cannot be considered proven.

In summary: the radionuclide method is not inferior to biochemical markers in assessing early postoperative renal dysfunction in regard to its diagnostic significance and informativeness.

Statement of Ethics.

The study protocol complied with the Declaration of Helsinki and was approved by the Ethics and Research Committee of Cardiology Research Institute, Tomsk National Research Medical Centre. All patients gave their written informed consent.

The authors declare no conflicts of interest.

Acknowledgment.

The article was prepared under the theme of fundamental research project No. AAAA-A15115123110026-3.

9. Cockcroft DW, Gault $M H$. Prediction of creatinine clearance from serum creatinine. Nephron 1976; 16: 31-41. DOI: 10.1159/000180580.

10. Chen LI, Guh JY, Wu KD, Chen YM, Kuo MC., Hwang SJ, et al. Modification of diet in Renal Disease (MDRD) Study and CKD Epidemiology Collaboration (CKD-EPI) Equations for Taiwanese Adults. PLoS One 2014; 9(6): e99645. DOI: 10.1371/journal.pone.0099645.

11. Branten AJW, Vervoort G, Wetzels JWM. Serum creatinine is a poor marker of GFR in nephrotic syndrome. Nephrol Dial Transplant 2005; 20: 707-711. DOI: 10.1093/ndt/gfh719.

12. Perrone RD, Madias NE, Levey AS. Serum creatinine as an index of renal function: new insights into old concepts. Clin Chem 1992; 38: 1933-1953. PMID: 1394976.

13. Dharnidharka VR, Kwon C, Stevens G. Serum cystatin C is superior to serum creatinine as a marker of kidney function: a meta-analysis. Am J Kidney Dis 2002; 40: 221-226. DOI:10.1053/ajkd.2002.34487.

14. Rickli H, Benou K, Ammann P, Fehr T, Brunner-La Rocca HP, Petridis $H$, et al. Time course of cystanin levels in comparison with serum creatinine after application of radiocontrast media. Clin Nephrol 2004; 61: 9098-9102. DOI: 10.5414/cnp61098.

15. Hawkins R. New biomarkers of acute kidney injury and the cardio-renal syndrome. Korean J Lab Med 2011; 31: 72-80. DOI: $10.3343 / \mathrm{kjlm} .2011 .31 .2 .72$.

16. Mori K, Lee HT, Rapoport D, Drexler IR, Foster K, Yang J, et al. Endocytic delivery of lipokalin-siderophore-iron complex rescues the kidney from ischemia-reperfusion injury. J Clin Invest 2005; 115: 610-621. DOI: 10.1172/JCI200523056.

17. Vesnina $Z h V$, Lishmanov YuB, Alexandrova EA, Nesterov EA. Evaluation of Nephroprotective Efficacy of Hypoxic Precondi- 


\section{RUSSIAN ELECTRONIC JOURNAL OF RADIOLOGY}

tioning in Patients Undergoing Coronary Artery Bypass Surgery. Cardiorenal Medicine 2016; 6: 328-336. DOI:10.1159/000446571.

18. Haase M, Bellomo R, Devarajan P, Schlattmann P, HaaseFielitz A. Accuracy of Neutrophil Gelatinase-Associated Lipocalin (NGAL) in Diagnosis and Prognosis in Acute Kidney Injury: A Systematic Review and Meta-analysis. Am J Kidney Dis 2009; 54(6): 1012-1024. DOI: 10.1053/j.ajkd.2009.07.020.

19. Choi KM, Lee JS, Kim EJ, Baik SH, Seo HS, Choi DS, et al. Implication of lipocalin-2 and visfatin levels in patients with coronary heart disease. Eur J Endocrinol 2008; 158(2): 203207. DOI: 10.1530/EJE-07-0633.

20. McAlister FA, Ezekowitz J, Tonelli M, Armstrong PW. Renal Insufficiency and Heart Failure: Prognostic and Therapeutic Implications From a Prospective Cohort Study. Circulation 2004; 109: 1004-1009. DOI: 10.1161/01.cir.0000116764.53225.A9

21. Eriksen R, Vegsundvaag J, Hole T, Morsto TH. Hepatic and renal haemodynamics changes in congestive heart disease. Tidsskr Nor Laegeforen 2006; 6: 743-746. PMID: 16541165.

22. Ix JH, Shlipak MG, Chertow GM, Whooley MA. Association of Cystatin $C$ with mortality, cardiovascular events, and incident heart failure among persons with coronary heart disease. Data From the Heart and Soul Study. Circulation 2007; 115: 173179. DOI: 10.1161/CIRCULATIONAHA.106.644286.

23. Galteau MM, Guyon M, Gueguen R, Siest G. Determination of serum cystatin $C$ : biological variation and reference values. Clin Chem Lab Med 2001; 39(9): 850-857. DOI: 10.1515/CCLM.2001.141.

24. Bolignano D, Lacquaniti A, Coppolino G, Donato V, Campo S, Fazio MR, et al. Neutrophil gelatinase associated lipocalin (NGAL) and progression of chronic kidney disease. Clin J Am Soc Nephrol 2009; 4(2): 337-344. DOI: 10.2215/CJN.03530708. 25. Bachorzewska-Gajewska H, Malyszko J, Sitniewska E, Malyszko JS, Dobrzycki S. Neutrophil gelatinase-associated lipocalin (NGAL) correlations with cystatin $C$, serum creatinine and eGFR in patients with normal serum creatinine undergoing coronary angiography. Nephrol Dial Transplant 2007; 22: 295296. DOI: 10.1093/ ndt/gfl408.

26. Dent CL, Ma Q, Dastrala S, Bennett M, Mitsnefes MM, Barasch $J$, et al. Plasma neutrophil gelatinase-associated lipocalin predicts acute kidney injury, morbidity and mortality after pediatric cardiac surgery: a prospective uncontrolled cohort study. Crit Care 2007; 11(6): R127. DOI: 10.1186/cc6192. 27. Schmidt-Ott KM, Mori K, Li J.Y, Kalandadze A, Cohen DJ, Devarajan P, et al. Dual Action of Neutrophil Gelatinase - Associated Lipocalin. J Am Soc Nephrol 2007; 18: 407-413. DOI: 10.1681/ASN.2006080882.

28. Abu-Omar Y, Ratnaunga C. Cardiopulmonary bypass and renal injury. Perfusion 2006; 21(4): 209-213. DOI: 10.1191/0267659106pf870oa.

29. Mishra J, Dent C, Tarabishi R, Mitsnefes MM, Ma Q, Kelly C, et al. Neutrophil gelatinase-associated lipocalin (NGAL) as a biomarker for acute renal injury after cardiac surgery. Lancet 2005; 365: 1231-1238. DOI:10.1016/SO140-6736(05)74811-X. 30. Rosner MH, Ocusa MD. Acute kidney injury associated with cardiac surgery. Clin J Am Soc Nephrol 2006; 1: 19-32. DOI: 10.2215/CJN.00240605.

31. Laterza OF, Price CP, Scott MG. Cystatin C: an improved estimator of glomerular filtration rate? Clin Chem 2002; 48: 699707. PMID: 11978596.

32. Haase-Fielitz A, Bellomo R, Devarajan P, Story D, Matalanis $G$, Dragun $D$, et al. Novel and conventional serum biomarkers predicting acute kidney injury in adult cardiac surgery - a prospective cohort study Crit Care Med 2009; 37: 553-560. DOI: 10.1097/CCM.Ob013e318195846e.

33. Podracka L, Feber J, Lepage N, Filler G. Intra-individual variation of cystatin $C$ and creatinine in pediatric solid organ transplant recipietnts. Pediatr Transplant 2005; 9(1): 28-32. DOI: 10.1111/j.1399-3046.2005.00235.x.

34. Risch L, Herklotz R, Blumberg A, Huber AR. Effects of glucocorticoid immunosuppression on serum cystatin $C$ concentration in renal transplant patients. Clin Chem 2001; 47: 2055-2059. PMID: 11673383.

35. Knight EL, Verhave JC, Spiegelmann D, Hillege HL, de Zeeuw D, Curhan GC, et al. Factors influencing serum cystanin $C$ levels other than renal function and the impact on the renal function measurement. Kidney Int 2004; 65: 1416-1421. DOI:10.1111/j.1523-1755.2004.00517.x.

36. Svensson AS, Kvitting JE, Kovesdy CP, Cederholm I, Szabó $Z$. Changes in serum cystatin $C$, creatinine, and $C$-reactive protein after cardiopulmonary bypass in patients with normal preoperative kidney function. Nephrology (Carlton) 2016; 21(6): 519-525. DOI: 10.1111/nep.12630. 